\title{
Okul öncesi dönem çocuklarında çalışma belleği ve engelleyici kontrol: Dikkatin aracı rolü
}

\author{
Working memory and inhibitory control in preschool children: The role \\ of attention as mediator
}

\author{
Ali İbrahim Can Gözüm ${ }^{1}$
}

\section{Makale Geçmişi \\ Geliş : : 7 Haziran 2020 \\ Düzeltme : 5 Ağustos 2020}

Kabul : 17 Ağustos 2020

\section{Makale Türü}

Arasturma Makalesi

\begin{abstract}
Article History
Received : 7 June 2020

Revised : 5 August 2020

Accepted : 17 August 2020
\end{abstract}

\section{Article Type}

Research Article

\begin{abstract}
Öz: $\mathrm{Bu}$ araștırmanın amacı, dikkat, çalıșma belleği ve engelleyici kontrol becerileri arasındaki ilișki ve çalışma belleği ile engelleyici kontrol arasında dikkatin aracı rolünün incelenmesidir. Araştırma, Kars ilinde kamu anaokuluna ve anasınıfina devam eden 60-72 aylık 200 çocuğun katılımıyla gerçekleştirilmiştir. Araşıırmada İvrendi ve Erol (2018) tarafindan geliştirilen 4-6 Yaş Cocuklarna Yönelike. Öz düzenleme Becerileri Ölçĕgi (Öğretmen Formu) kullanılmıștır. Veri toplama aracına yapılan Doğrulayıcı Faktör Analizi (DFA) ve iç tutarlık analizine göre veri toplama aracının geçerli ve güvenilir olduğu tespit edilmiştir. Araştırmanın sonucunda çalışma belleği, dikkat ve engelleyici kontrol becerilerinin doğrudan ve olumlu yönde etkilemektedir. Dikkat, engelleyici kontrolü doğrudan ve olumlu yönde etkilemektedir. Basit etki modeli ile aracı etki modeli karşılaştırıldığında, çalışma belleği ve engelleyici kontrol arasında ilişki azalmış ancak anlamlı farklılık ortadan kalkmadığı için dikkatin çalışma belleği ve engelleyici kontrol arasında kısmi aracı etkiye sahip olduğu tespit edilmiştir. Araştırmada önerilen modele ait bulgular alanyazına göre incelenmiş, çalışma belleği, dikkat ve engeleyici kontrolün işlevsel özellikleri ve etkileşimi tartısılmıstır.
\end{abstract}

Anahtar Kelimeler: Okul öncesi dönem çocukları, Çalışma belleği, Engelleyici kontrol, Dikkat

Abstract: The aim of this study was to investigate the relationship between attention, working memory, and inhibitory control skills and the role of attention as a mediator variable between working memory and inhibitory control. The study was carried out with the participation of 200 children aged 60-72 months attending a state-run kindergarten in Kars province. The Self-Regulation Skills Form for Children Aged 4 to 6 (Teacher's Form) developed by İvrendi and Erol (2018) was used in the study. According to the Confirmatory Factor Analysis (CFA) and internal consistency analysis made of the data collection tool, the data collection tool was found to be valid and reliable. According to the results of the study, working memory directly and positively affects attention and inhibitory control skills. Attention directly and positively affects inhibitory control. Attention was found to have a partial mediating effect between working memory and inhibitory control. The findings of the proposed model in the study were invastigated according to the literature. The interaction of functional features of working memory, attention, and inhibitory control was discussed.

Key Words: Preschool children, Working memory, Inhibitory control, Attention 


\section{SUMMARY}

\section{Introduction}

Self-regulation is defined as children's ability to control and regulate their emotions, thoughts, attention, and behavior (Vosh and Baumiester, 2004; Zimmerman, 2000). Self-regulatory attention or cognitive flexibility involves the ability for working memory and inhibitory control to be organized as functional behaviors (McClelland et al., 2014; McClelland and Cameron, 2012). These cognitive components under self-regulation are among its components in its executive functions. (Gözüm, Coşkun, and İpek, 2019). Relationships between attention and working memory occur under the control of executive functions. Executive functions interact with children's behavioral controls, cognitive skills, and social and emotional development (Dawson and Guare, 2010).

It is emphasized that the development of children's working memory, attention, and inhibitory control skills have an important effect on academic success (Baumeister and Vohs, 2004; McClelland et al., 2007a; McClelland, Cameron, Wanless and Muray, 2007b). It has been determined that there is a relationship between self-regulatory skill in preschool children and their mathematics and literary skills and that attention (Blair, Knipe and Gamson, 2008; Blair and Raver, 2015; Blair and Razza, 2007; Howse, Lange, Farran and Boyles, 2003), working memory (Berg, 2008; Bryce, Whitebread and Szúcs, 2015; Gathercole and Pickering, 2000), and inhibitory control play an active role (Blair and Razza, 2007; Riggs, Blair and Greenberg, 2003) in academic success. In this context, it is also important to identify the relationship between attention, working memory, and inhibitory control skills, the support of which in children's preschool and later life is very important. The aim of this study is to investigate the relationship between attention, working memory, and inhibitory control skills and the role of attention as a mediator variable between working memory and inhibitory control. In this context, the hypotheses of the research model proposed for attention, working memory, and inhibitory control are given below.

$\mathrm{H}_{1}$ : Working Memory has a significant effect on inhibitory control.

$\mathrm{H}_{2}$ : Working Memory has a significant effect on attention.

$\mathrm{H}_{3}$ Attention has a significant effect on inhibitory control.

$\mathrm{H}_{4}$ : Attention is a significant mediator variable between working memory and inhibitory control.

\section{Method}

The relational screening method, which is suitable for qualitative research, was used in this study. It is a research model that looks at the relationship between two or more variables and the degree of relationship. (Karasar, 2006). In this regard, the aim is to test the hypotheses for the model of 
the mediator variable proposed between working memory, attention, and inhibitory control. Appropriate to the relational screening method used in the study, the Structural Equation Model was used as the method of analysis.

The study was carried out with the participation of 200 children aged 60-72 months attending a state-run kindergarten in Kars province. The participants of the study consist of children with normal development selected at random using the general screening method (Karasar, 2006).

\section{Data Collection Tools}

In the study, a data collection form consisting of two sections was used. The first part of the form asks about the participants' demographic characteristics (gender, order of birth, number of children in the family). The second part includes the "Self-regulation Skills Scale for Children Aged 4-6 (Teacher's Form)" developed by Ivrendi and Erol, (2018) The validity and reliability values for the "Selfregulation Skills Scale for Children Aged 4-6 Years (Teacher's Form) used in the study are given below.

When the fit index values of the self-regulation skills scale $\left[\chi^{2}=939.831 ;(\mathrm{df}=202, \mathrm{p}<.001)\right.$; $\chi 2 / \mathrm{sd}=4.653 ;$ RMSEA $=0.068, \mathrm{NFI}=0.904, \mathrm{CFI}=0.912, \mathrm{GFI}=0.905, \mathrm{AGFI}=0.923, \mathrm{IFI}=0.935]$ were examined, the $\chi^{2}$ / sd (Anderson and Gerbing, 1984; Kline, 2016), RMSEA (Jöreskog and Sörbom, 1993; Hu and Bentler, 1998), NFU (Hu and Bentler, 1998; Tabachnick and Fidell, 2013), CFU (Tabachnick and Fidell, 2013), GFI (Shevlin and Miles, 1998; Hooper et al., 2008) and IFI (Marsh and Hau, 1996) values were determined to be in the good fit value range according to the literature.

The internal consistency coefficient (Cronbach Alpha) was examined to check the reliability values of the data collection tool. The internal consistency coefficient of working memory is 0.939 . The internal consistency coefficient of the attention factor is 0.785 . The internal consistency coefficient of working memory is 0.900 . Accordingly, it was determined that the data collection tool is reliable.

\section{Results}

According to the results of the study, working memory directly and positively affects attention and inhibitory control skills. Attention directly and positively affects inhibitory control. When the simple effect model and the intermediate effect model are compared, it is understood that the relationship between working memory and inhibitory control has decreased but since there is still a significant difference, attention has a partial mediating effect between working memory and inhibitory control. 


\section{Conclusion and Discussion}

Attention, working memory, and inhibitory control are related to each other, and discussions about how they affect each other are reviewed and examined in a theoretical context. According to the result of the study's first hypothesis, working memory directly and positively affects inhibitory control. Indeed, in their study, Bryce and Whitebread (2012) argued there is a relationship between memory and impulse control. Ivrendi and Erol (2018) in their study found a significant relationship between working memory and inhibitory control. Swanson and Beebe-Frankenberger (2004) found that children with limited working memory had difficulty in learning how to combine old and new information without support. In this context, Blair and Razza (2007) argued on the basis of mathematics achievement after preschool that working memory improved in children with developed inhibitory control skills. Berg (2008) in his study determined that there is a high relationship between working memory and mathematics skills. In light of these studies, it can be said that the relationship between working memory and inhibitory control has a significant effect on children's academic success.

Beck et al (2010) advocated improving the working memory of children who have problems with attention control. A direct relationship between working memory and attention has been identified in the literature (İvrendi and Erol, 2018; McCabe et al. 2010; Parker, 2001;Shipstead, Lindsey, Marshall and Engle, 2014; Shipstead. Martin and Nespodzany, 2019; Swayze and Dexter, 2017). According to the results of the second hypothesis of the study, working memory has a direct and positive effect on attention. In this context, it can be said that the development of working memory positively affects the development of attention. The relationship between working memory and the development of attention can be directly observed in children's academic success. Duncan et al (2007) in their study reported that development of the attention skill contributes to the development of reading and mathematics skills. Studies advocating a relationship between children's attention skills and their mathematics and reading skills (Altemeier, Abbott and Berninger, 2008; Blair and Raver, 2015; Blair, Knipe and Gamson, 2008; Walcott, Scheemak and Bielski, 2010) have been found in the literature. In this context, it can be argued that the relationship between children's working memory and attention affects their learning capacity with a resulting increase in academic achievement being observed.

Children who cannot control their attention skills are observed to have problems regulating their inhibitory control behaviors (Meltzer and Krishnan, 2007; Shanahan, Pennington and Willcutt, 2008). According to the results of the third hypothesis of the study, development of the attention skill enables the development of inhibitory control. This being the case, enabling children's 
attention control, will, according to Macdonald, Beauchamp, Crigan and Anderson, (2014), enable children with inhibitory control behavior to manage their inner impulses, increase self-control, and prevent stimulating behaviors. Indeed, inhibitory control skills are associated with children's cognitive, social, and academic development. (Ertürk Kara, Güler Yıldız and Fındık, 2018). Therefore, supporting attention development in children will develop their inhibitory control skills, and, as a result, ensure a healthy future for children in the years to come. As a matter of fact, physical health problems, substance addiction, and criminal behaviors can be observed together with attention deficit disorders in children who fail to develop inhibitory control skills. (Moffitt et al., 2011).

According to the findings of the study, working memory and attention directly and positive affect inhibitory control. However, attention causes a mediator effect between working memory and inhibitory control. The relationship between attention and working memory (Awh, Jonides, and Reuter-Lorenz, 1998; Chun, 2011; Gazzaley and Nobre, 2012; Kiyonaga and Egner, 2014; Oberauer, 2009; Olivers, 2008) has been identified in many studies. However, according to Oberauer (2019), the fact that working memory has an effect on inhibitory control behavior through attention shows that information retained in working memory regulates behavior as a result of attention being maintained. The significant results of attention as a mediator variable reveal, according to the study by Robert et al. (2009), the effect of attention on inhibitory control skills throughout an individual's life. It is understood from this that supporting the development of working memory and attention in children has a positive effect on the development of inhibitory control behaviors. 


\section{GİRIŞ}

Erken çocukluk yıllarında çocuklar dikkatlerini toplamayı, belleklerini kullanmayı ve otomatik yanıtlanı engellemeyi deneyimleyerek öz düzenleme becerilerini kontrol etmeyi çok hızlı öğrenirler (Cameron Ponitz, McClelland, Matthews ve Morrison, 2009; McClelland ve diğerleri, 2014; McClelland ve Cameron, 2012). Çocuklarda öz düzenlemenin temelini oluşturan bilişsel becerilerin hızlı gelişimi ve deneyimleyerek öğrenme, olgunlaşmayla birlikte proaktif, planlı ve bilinçli davranışların oluşmasını sağlar (Best ve Miller, 2010; Bronson, 2000). Çocukların bilinçli davranışları sergilemesinin altında plastisite döneminde sinir ağlarının budanması ve oluşmasının kritik önemi vardır. Çocukların sinir ağlarında meydana gelen budama ya da yeni sinaptik bağlantıların oluşumunde çevresel müdahalenin kritik olduğu yıllar erken çocukluk yıllarıdır. Çocukların dikkat, bellek, alg1, planlama, organizasyon, sorumluluk alma, işbirliği, problem çözme, iletişim, yaratıc1lık, zihinsel esneklik gibi becerilerin gelişiminin desteklenmesi, yaşamı boyunca kazanacağı beceriler için gerekli olan sinaptik bağlatılarının oluşumunu sağlamaktadır (Bee ve Boyd, 2009; Fischer, 2008; Nelson, 2002; Ram-Tsur, 2013). Bu bağlamda çocukların kazanacağ1 beceriler ve gelecekteki yaşam kaliteleri için gerekli olan nöral ağları oluşturacak öz düzenleme becerilerinin erken yaşlarda desteklenmesi son derece önemlidir (Bronson, 2000).

Çocukların duygu, düşünce, dikkat ve davranışlarını kontrol edip düzenlenmesi öz- düzenleme olarak tanımlanmaktadır (Vosh ve Baumiester, 2004; Zimmerman, 2000). Öz-düzenleme; dikkat veya bilişsel esneklik, çalışma belleği ve engelleyici kontrolün bir arada işlevsel olarak, organize edilme yeteneğini içerir ( McClelland ve diğerleri, 2014; McClelland ve Cameron, 2012 ). Öz düzenleme kapsamında yer alan bu bilişsel bileşenler yürütücü işlevlerinde bileşenleri arasındadır (Gözüm, Coşkun ve İpek, 2019). Dikkat ve çalışma belleği arasındaki ilişkiler yürütücü işlevlerin kontrolü altında gerçekleşmektedir. Yürütücü işlevler çocukların davranış kontrolleri, bilişsel becerileri, sosyal ve duygusal gelişimleriyle etkileşim içerisindedir (Dawson ve Guare, 2010).

Norris ve Tate (2000) tarafindan yapılan araştırmada, yürütücü işlevlerde meydana gelen işlevsel bozuklukların, dikkati toplayamama, hatırlamanın yavaşlaması ve dürtüselliğin kontrol edilememesi gibi sonuçlara neden olduğu tespit edilmiştir. Öz düzenleme becerilerinin bilişsel düzenleme becerisi altında dikkat ve çalışma belleği, davranış düzenleme becerileri altında ise engelleyici kontrol yer almaktadır (Ertürk Kara, Güler Yıldız ve Fındık, 2018).

Dikkat, çevreden gelen uyaranlar arasında istenilen uyarana yönelirken istenilmeyen uyaranların görmezden gelme ve amaca yönelik davranıss sürecinde odaklanmanın sürdürülmesidir (Anderson, 2005). Konuya ilişkin araştırmalar incelendiğinde; Duncan ve diğerleri (2007) tarafindan yapılan 
araştırmada okul öncesi dönem 60-72 aylık çocuklarda dikkat; düzenlenme becerisi, okuma ve matematik becerilerinin anlamlı yordayıcısı olduğu tespit edilmiştir.

Moffitt ve diğerleri (2011) tarafindan yapılan araştırmada dikkat sürekliliğini içeren erken öz kontrol becerisinin desteklenmemesi ve gelişmemesi sonucunda yetişkinlikte; fiziksel sağlık bozukluğu, madde bağımlılığı, suç oluşturan davranışların gözlemlenebildiği tespit edilmiştir. Erken yıllarda öz düzenleme becerileri gelişen çocukların, matematiksel problemlerde dikkatlerini toplayarak ve göz ardı etmesi gereken uyaranları bilinçli kontrol ederek, matematiksel problemleri çözebildikleri belirlenmiştir (Blair, Knipe ve Gamson, 2008; Blair ve Raver, 2015 ). Dikkat becerisini bilinçli kontrol edebilen çocukların bir kelimenin anlamına odaklanırken, yapısal özelliklerini belirlemek için dikkatlerini amaca yönelik yönlendirebildikleri anlaşılmaktadır (Altemeier, Abbott ve Berninger, 2008; Walcott, Scheemaker ve Bielski, 2010).

Çalışma belleği, çocukların bir görevi tamamlamak için bilgiyi yeterli sürede hafızada tutabilme yeteneğidir (Adams, Bourke ve Willis, 1999). Çalışma belleği, çok aşamalı görevlerin tamamlandığında yönergeler boyunca takip edilen bellek bileşeninin diğer bilişsel becerilerle aktif ilişkide olduğu boyutudur (Tominey ve McCleland, 2011). Bu bağlamda çalışma belleği ile ilişskili bilişsel ve sosyal beceriler incelenmiştir. Bryce, Whitebread ve Szúcs (2015) tarafindan yapılan araştırmada, 5-7 yaş grubundaki çocukların çalışma belleği ve üst bilişsel beceriler arasında ilişki saptanmıştır. Çocukların çalışma belleği ve üst bilişsel becerilerin akademik başarıları ile ilişkili olduğu da tespit edilmiştir. Bryce ve Whitebread (2012) tarafindan yapılan araştırmada, 60 aylık çocukların problem çözme görevleri gözlemlenerek bağımsız öğrenme davranışları incelemiştir. Araştırmanın sonucunda, kısa süreli bellek ile dürtü kontrolü arasında ilişki tespit edilmiştir. Swanson ve Beebe-Frankenberger (2004) tarafindan yapılan araştırmada, çalışma belleği kapasiteleri sınırlı olan çocukların öğrendikleri yeni bilgiler ile eski bilgileri bütünleştirmekte güçlük çektikleri belirlenmiştir. Berg (2008) tarafından yapılan araştırmada yaş değişkeni sabit tutulduğunda çalışma belleği ve matematik becerileri arasında yüksek ilişki saptanmıştır. Araştırmalar ışığında çalışma belleğinin hem bilişsel hem de sosyal becerileri ile ilişkili olduğu anlaşılmaktadır.

Engelleyici kontrol, bireyin uygun davranışı gösterebilmek için amaç dışında ortaya çıkan baskın ve otomatik davranışı durdurma becerisidir. Örneğin çocukların sorulan soruya aniden yanıt vermek yerine el kaldırma ve bekleme becerisi ya da isminin çağrılmasını bekleyen çocuğun bekleme sürecinde sergilemesi beklenilen davranışın otomatik ortaya çıkışını düzenlemesidir (McClelland, Cameron, Wanless ve Murray, 2007b; Rennie, Bull ve Diamond, 2004). Blair ve Razza (2007) tarafından yapılan araştırmanın sonucuna göre, okul öncesi dönem çocuklarının engelleyici kontrol 
gelişiminin desteklenmesi, okul döneminde matematik başarısını artırmasında etkilidir. Erken çocukluk yıllarında ailelerin çocuklarının öz düzenleme becerilerini desteklemesi engelleyici kontrol becerisinin gelissimini de desteklemektedir (Dearing ve diğerleri 2006; Lareau, 2003). Düşük gelirli aileler çocuklarına öz düzenleme becerilerini destekleyici daha az görev ve sorumluluk vermektedir. Düşük gelirli ailelerin çocukları anaokuluna gidememe riski de vardır. Bu nedenlerden dolayı gelir düzeyi düşük ailelerin çocuklarında engelleyici kontrol becerisi istenilen düzeyde gelişmemektedir (Evans ve Rosenbaum, 2008; Howse, Lange, Farran ve Boyles, 2003). Bu bağlamda çocukların engelleyici kontrol gelişiminin desteklenmesinde öncelikle ebeveynlerin daha sonra öğretmenlerin etkili olduğu söylenebilir.

Çalışma belleği, dikkat ve engelleyici kontrol arasındaki ilişkiyi araştıran çalışmalara yönelik alanyazın taraması yapılmıştır. Çalışma belleği ve engelleyici kontrol arasında ilişki tespit edilen araştırmalar (Ford, McDougall ve Evans, 2009; Landry ve diğerleri, 2000; Passolunghi ve Siegel, 2001; St. Clair-Thompson, Stevens, Hunt ve Bolder, 2010 ), çalışma belleği ve dikkat arasında ilişki olduğunu belirleyen araştırmalar (Klingberg, Forssberg ve Westerberg, 2002; Beck, Hanson, Puffenberger, Benninger ve Benninger, 2010; Kar ve Kenderla, 2017), dikkat ve engelleyici kontrol arasında ilişki olduğu saptanan araştırmalar (Sweeney, Rosano, Berman ve Luna, 2001; Johnson, White, Wong ve Murrihy, 2019), çalışma belleği, dikkat ve engelleyici kontrol arasındaki ilişkiyi araştıran çalışmalar (Sonuga-Barke, Dalen, Daley, Remington, 2002; Stevens, Quittner, Zuckerman ve Moore,2002; Raver ve Blair , 2016) alanyazında mevcuttur. Alanyazı taramas1 sonucunda; çalışma belleği, dikkat ve engelleyici kontrol becerileri arasında ilişki olduğu tespit edilmiştir.

Alanyazında çocukların çalışma belleği, dikkat ve engelleyici kontrol becerilerinin gelişiminin akademik başarı üzerinde önemli etkiye sahip olduğu da vurgulanmaktadır (Baumeister ve Vohs, 2004; McClelland ve diğerleri, 2007a; McClelland ve diğerleri 2007b). Okul öncesi dönem çocuklarında öz düzenleme becerisi ile matematik, okuryazarlık becerilerinin ilişkili olduğu ve akademik başarının artmasında dikkatin (Blair, Knipe ve Gamson, 2008; Blair ve Raver, 2015; Blair ve Razza, 2007; Howse ve diğerleri, 2003), çalışma belleğinin (Berg, 2008; Bryce, Whitebread ve Szúcs, 2015; Bull, Espy ve Wiebe, 2008; Gathercole ve Pickering, 2000) ve engelleyici kontrolün (Blair ve Razza, 2007; Riggs, Balir ve Greenber, 2003) etkin rol oynadığ1 tespit edilmiştir.

Erken çocukluk dönemi ve sonraki dönemlerde çalışma belleği, dikkat ve engelleyici kontrolün kritik önemi, yukarıda verilen araştırmalar ışığında vurgulanmıştır. Bu bağlamda alanyazında tespit edilen dikkat, çalışma belleği ve engelleyici kontrol becerileri arasındaki ilişkinin 60-72 aylık çocuklar 
üzerinde incelenmesi alanyazına katkı sunacağ1 düşünülmektedir. Bu noktadan hareketle bu araştırmanın amacı; dikkat, çalışma belleği ve engelleyici kontrol becerileri arasındaki ilişki ve çalışma belleği ile engelleyici kontrol arasında dikkatin aracı değişken rolünün incelenmesidir. $\mathrm{Bu}$ amaç doğrultusunda model ve hipotezler başlı̆̆1 altında kuramsal bilgi ve araştırmalara göre aracı değişken modeli önerilmiştir.

\section{Model ve Hipotezler}

Dikkat, çalışma belleği ve engelleyici kontrol arasındaki ilişkiyi incelemek amacıyla önerilen modelin kuramsal incelemesi ve hipotezleri, test edilecek olan hipotez başlıklarına göre sırasıyla aşağıda açıklanmıştır.

\section{Çalışma Bellĕ̆i- Engelleyici Kontrol}

Çalışma belleği ve engelleyici kontrol becerileri çeşitli uygulamalarla desteklenirse geliştirilebilir. Çalışma belleğinin desteklendiği ve geliştirildiği durumda çocuklarda engelleyici kontrolün geliştiği tespit edilmiştir (Ford, McDougall ve Evans, 2009; Landry ve diğerleri, 2000; St. Clair-Thompson, Stevens, Hunt ve Bolder, 2010). Maraver, Bajo ve Gomez-Ariza (2016) tarafindan yapilan deneysel araştırmada katılımcılara, yürütücü işlev kontrolü, inhibitör kontrol, çalşma belleği, aktif kontrol, transfer görevleri ve çalışma aralığı başlıklı eğitim etkinliklerinden oluşan altı oturumluk eğitim uygulanması sonucunda çalışma belleği ve engelleyici kontrol davranışlarının gelişiminin desteklendiği tespit edilmiştir.

Traverso, Mantini, Usai ve Viterbori (2015) tarafindan 36-60 ay arasındaki çocuklar üzerinde yapılan araştırmada, engelleyici kontrollerin sözel ve uzamsal çalışma belleğinden etkilendiği tespit edilmiştir. Çalışma belleğinin engelleyici kontrol üzerinde anlamlı yordayıcı olduğunu tespit eden araştırmalar mevcuttur (Kane ve diğerleri, 2001; Unsworth, Schrock ve Engle, 2004;Tiego, Testa, Bellgrove, Pantelis ve Whittle, 2018). Bu araştırmalar ışı̆̆ında çalışma belleği ve engelleyici kontrol arasındaki ilişkiyi tespit etmek için araştırmanın birinci hipotezi $\left(\mathrm{H}_{1}\right)$; " $\mathrm{H}_{1}$ : Çalışma Belleği, engelleyici kontrol üzerinde anlamlı etkisi vardır.” olarak belirlenmiştir.

\section{Çalışma Bellĕ̆gi- Dikkat}

Sözel, işitsel ve görsel uyaranların geçici olarak hafızaya alınması, depolanması ve bilişsel süreçlerin planlanması, düzenlenmesi ve dikkatin kontrolünün sağlanmasında çalışma belleği görev almaktadır (Baddeley, 1986). Beck ve diğerleri (2010) tarafından yapılan araştırmada, dikkat kontrol becerisi sorunu yaşayan çocukların çalışma belleğinin güçlendirilmesinin dikkat sorununu azaltacağını 
savunmaktadır. Swayze ve Dexter (2017) tarafindan yapılan araştırmada 36-48 ay çocukların çalışma belleği ve dikkat arasında anlamlı ilişkinin olduğu tespit edilmiştir. Parker (2001) tarafindan yapılan araştırmada, 24-60 ay arasında çocuklardan oluşan örneklemden oluşan çocuklarda bellek ve dikkat arasındaki ilişki incelenmiş ve anlamlı ilişki tespit edilmiştir. McCabe ve diğerleri (2010) tarafından yapılan araştırmada çalışma belleği ve yürütücü işlevler arasında yüksek ilişki olduğu tespit edilmiştir. Araştırmanın bir diğer önemli sonucu ise çalışma belleği ve yürütücü işlev becerileri arasında yürütücü dikkatin önemli bir değişken olduğu tespit edilmiştir. Shipstead, Martin ve Nespodzany (2019) tarafindan yapılan araştırmada, görsel uzamsal çalışma belleğinin işitsel ayırıcılık ve dikkat arasındaki ilişki incelenmiştir. Sürekli dikkat ve dikkat kontrolü, çalışma belleğinin anlamlı yordayıcısı olarak varyansın \%60’ inı açıklamaktadır. Shipstead, Lindsey, Marshall ve Engle (2014) tarafindan yapılan araştırmada çalışma belleğinin kapasiteleri olarak karmaşık aralık (işleme ve depolama) ve görsel diziler (değişiklik alg1lama) performans1, dikkat kontrolü ile güçlü bir şekilde ilişkiliyken, bellek aralığ1 (listedeki son n öğe için bellek) performansının birincil bellekle bir ilişkisi olduğu tespit edilmiştir. Buna göre, farklı model önerilerinde çalışma belleği kapasitesi ve dikkat kontrolü arasında çift yönlü ilişki olduğu anlaşılmaktadır. Bu noktadan hareketle araştırmanın ikinci hipotezi $\left(\mathrm{H}_{2}\right)$; “ $\mathrm{H}_{2}$ : Çalışma Belleği, dikkat üzerinde anlamlı etkisi vardır.” olarak belirlenmiştir.

\section{Dikkat-Engelleyici Kontrol}

Çocuklar dikkatlerini toplamayı öğrenebilirlerse duygu, düşünce ve davranışlarını etkili bir şekilde düzenleyerek olumsuz duygu, düşünce ve davranışlarının önüne geçebilirler (Eisenberg ve diğerleri, 1996; Mischel, 1974). Dikkat becerisini kontrol edemeyen çocuklarda engelleyici kontrol davranışlarını düzenleme problemleri gözlemlenmektedir (Meltzer ve Krishnan, 2007; Shanahan, Pennington ve Willcutt, 2008). Engelleyici kontrol davranışlarında sorun olan çocuklar; iç tepisel dürtü kontrol zorluğu, oto kontrol ve hazzı ertelemede güçlük yaşamaktadırlar (Macdonald, Beauchamp, Crigan ve Anderson, 2014). Johnson, White, Wong ve Murrihy (2019) tarafindan yapılan araştırmada 22 çocuğun öğretmenler tarafindan davranış gözlem derecelemelerine göre elde edilen sonuçlarına göre dikkat ve engelleyici kontrol arasında ilişki tespit edilmiştir. Bu bağlamda dikkat ve engelleyici kontrol arasında dikkatin engelleyici kontrol arasındaki ilişkiyi belirlemek için araştırmanın üçüncü hipotezi $\left(\mathrm{H}_{3}\right)$; “ $\mathrm{H}_{3}$ :Dikkatin, engelleyici kontrol üzerinde anlamlı etkisi vardır." olarak belirlenmiştir.

\section{Aracı Değişken olarak Dikkat}

Dikkat ve çalışma belleği arasında ilişki olduğu birçok kuram tarafından kabul edilmektedir (Awh, Jonides ve Reuter-Lorenz, 1998; Chun, 2011; Gazzaley ve Nobre, 2012; Kiyonaga ve Egner, 
2014; Oberauer, 2009; Olivers, 2008). Oberauer' a (2019) göre, dikkatin çalışma belleği üzerinde iki önemli rolü vardır. Birinci rolü belleğe gelecek uyaranlardan istendik uyaranı almada filtre görevi görmesi, ikinci rolü ise çalışma belleğine gelen uyaranın zihinde tutulması ve yönergelere göre dikkatin sürdürülerek davranışın düzenlemesini kontrol etme becerisidir. Bu araştırmada dikkatin çalışma belleğinde tutulan bilgiye göre amaçlanan davranışı sergilemek için engelleyici kontrol sürecinde dikkatin sürdürülmesine aracı değişken olarak incelenmesidir. Ertürk Kara, Güler Yıldız ve Fındık’a (2018) göre dikkat çeken her uyaran ancak çalışma belleğinde kalırsa birey daha sonraki davranışları kontrol etmede etkili olabilir. Nitekim, yürütücü dikkat bireyin ilgisini çeken uyarana yönelmek istemesine rağmen amaca yönelik uyaran üzerinde dikkatin sürmesini sağlamaktadır. Birey çalışan bellekten gelen yönergeye göre dikkatini sürdürmekte ve amaca yönelik davranış için istenmeyen davranışlarda engelleyici kontrol becerisini kullanmaktadır (Oberauer, 2019; Eisenberg ve Spinrad, 2004). Robert ve diğerleri (2009) tarafindan yapılan araştırmada, çocukluk döneminden yaşlilık dönemi süresinde çalışma belleği ve engelleyici kontrol arasındaki ilişkide dikkatin rolü incelenmiştir. Araştırmanın sonucunda çalışma belleği ve engelleyici kontrol arasındaki ilişkide dikkatin yaşam boyu engelleyici kontrol üzerinde önemli bir etkisi olduğu tespit edilmiştir. $\mathrm{Bu}$ bağlamda çalışma belleği ve engelleyici kontrol arasında aracı değişken olarak dikkat ilişkisini tespit etmek için araştırmanın dördüncü hipotezi $\left(\mathrm{H}_{4}\right)$; “ $\mathrm{H}_{4}$ : Dikkat, çalışma belleği ve engelleyici kontrol arasında anlamlı aracı değişkendir" olarak belirlenmiştir.

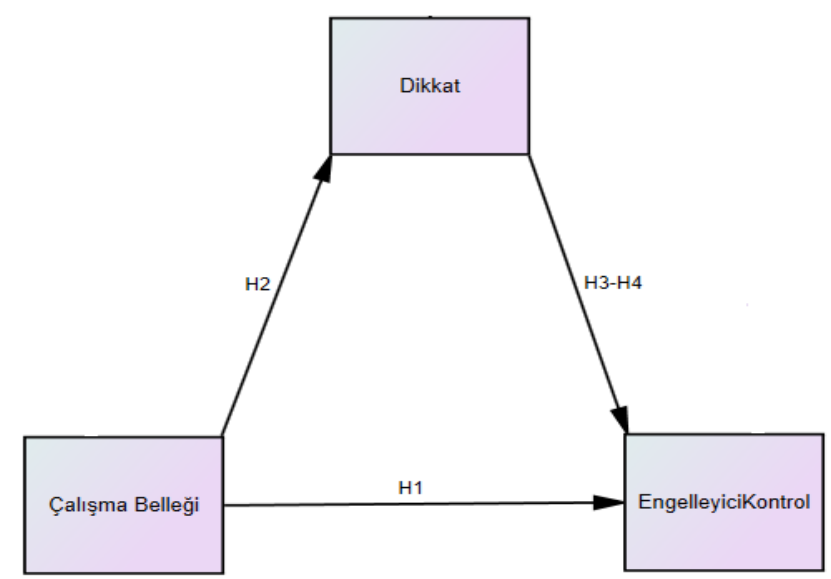

Şekil 1. Araştırmada önerilen aracı etki modeli ve hipotezleri.

Şekil 1'de dikkat, çalışma belleği ve engelleyici kontrol arasında önerilen modelin hipotezlerine aşağıda yer verilmiştir. 
$\mathrm{H}_{1}$ : Çalışma Belleği, engelleyici kontrol üzerinde anlamlı etkisi vardır.

$\mathrm{H}_{2}$ : Çalışma Belleği, dikkat üzerinde anlamlı etkisi vardır.

$\mathrm{H}_{3}$ : Dikkatin, engelleyici kontrol üzerinde anlamlı etkisi vardır.

$\mathrm{H}_{4}$ : Dikkat, çalışma belleği ve engelleyici kontrol arasında anlamlı aracı değisskendir.

\section{YÖNTEM}

Araştırmada nicel araştırma yöntemine uygun ilişkisel tarama metodu kullanılmıştır. İlişkisel tarama, iki ve daha çok değişken arasındaki ilişkiyi ve ilişkinin derecesini belirlemeyi amaçlayan bir araştırma metodur (Karasar, 2006). Bu bağlamda çalışma belleği, dikkat ve engelleyici kontrol arasında önerilen aracı değişken modelinin hipotezlerinin test edilmesi amaçlanmaktadır. Araştırmada kullanılan ilişkisel tarama metoduna uygun analiz metodu olarak Yapısal Eşitlik Modeli (YEM ) kullanılmıştır.

\section{Çalışma Grubu}

Araştırmanın çalışma grubu, Kars ilinde kamu anaokuluna ve ilkokula bağlı anasınıflarına devam eden 60-72 aylık 200 çocuktan ve 12 okul öncesi öğretmeninden oluşmaktadır. Araştırmanın katılımcıları genel tarama metoduna uygun seçkisiz örnekleme yöntemine göre herhangi bir gelişimsel tanı konulmamış, tipik gelişim gösteren ve araştırmaya katılmaya istekli çocuklar ve bu çocukların öğretmenlerinden oluşmuştur (Karasar, 2006). Çocuklara ait demografik özellikler incelendiğinde, \% 52'sinin kız ( $\mathrm{n}=104)$, \% 48'inin erkek ( $\mathrm{n}=96)$ olduğu tespit edilmiştir. Çocukların yaş ortalaması yaklaşık olarak 66 aylıktır.

\section{Verilerin Toplanmas1}

Kars İl Milli Eğitim Müdürlüğünden verilerin toplanması için gerekli izinler alınmıştır. Veriler Kars il merkezine bağlı resmi bağımsız anaokulu ve ilköğretim okullarının anasınıflarından 2018-2019 eğitim öğretim yılında toplanmıştır. Araştırmanın çalışma grubu, aileleri tarafindan araştırmaya gönüllü katılmak istediklerine dair onam formu doldurulan çocuklardan oluşmaktadır. Araştırmanın amacı öğretmenlere açıklanmıştır. Veri toplama süreci 12 okul öncesi öğretmeni ile yürütülmüştür. Veri toplama aracı formu asıl uygulanmadan önce öğretmenlerle pilot uygulaması yapılarak uygulanabilirliği kontrol edilmiştir. Pilot uygulama sürecinde öğretmenlerin sordukları sorular araştırmacı tarafindan yanıtlanmıştır. Pilot uygulama sonucunda öğretmenler formu uygulamaya hazır olduklarını ifade etmişlerdir. Öğretmenler veri toplama süresinden önce çocuklara 10 hafta 
eğitim yaptıkları ve çocukları iyi tanıdıklarını belirtmişlerdir. Öğretmenlerin çocuklara yönelik gözlemleri olmasına rağmen 1 hafta ölçek maddelerine yönelik gözlem yapmaları ve anekdot tutmaları istenmiştir. Öğretmenlerin tuttuğu anekdot kayıtlarına göre 1 hafta içinde veri toplama aracını doldurmaları istenmiştir. Veriler, katılımcı çocukların öğretmenlerinin gözlemlerine göre sınıf ortamından toplanmıştır. Öğretmeler tarafindan doldurulan formlar yalnızca araştırmacı tarafından gizliliği korunmak ve bilimsel araştırmada kullanılmak amacıyla toplandığı, ebeveyn ve öğretmenlere belirtilmiştir. Toplanan veriler araştırmacı tarafından çocukların kimlik bilgilerini tespit edilmeyecek şekilde kodlanarak gözden geçirilmiş eksik ya da hatalı doldurmalara karşı öğretmenlerle görüşme yapılmıştır.

\section{Veri Toplama Araçları}

Araştırmada iki bölümden oluşan veri toplama formu kullanılmıştır. Formun ilk bölümünde katılımcıların demografik özellikler (cinsiyet ve yaşı) hakkında sorulara yer verilmiştir. İkinci bölümünde "4-6 Yaş Cocuklarna Yönelik Öz düzenleme Becerileri Ölçeği (Öğretmen Formu)” yer almaktadır. Araştırmada kullanılan veri toplama aracının geliştiren araştırmacıların geçerlik ve güvenilirliğine ait yaptıkları araştırma sonuçlarına aşağıda yer verilmiştir.

\section{4-6 Yaş Çocuklarına Yönelik Öz düzenleme Becerileri Ölçeği (Öğretmen formu)}

Öz düzenleme becerileri ölçeği İvrendi ve Erol (2018) tarafindan geliştirilmiştir. 438 çocuğa ait ölçek formu 20 okul öncesi öğretmeni tarafindan doldurulmuştur. Ölçeğin yap1 geçerliği için Açımlayacı Faktör Analizi (AFA) ve Doğrulayıcı Faktör Analizi (DFA) yapılmıştır. AFA sonucunda veri setinin toplam varyans1 $\% 63$ 'ünü açıkladığı tespit edilmiştir. Temel bileşenler analizi prensibine göre yapılan faktörleştirme işleminde üç faktörlü yapı elde edilmiştir. Elde edilen faktörlere dikkat, engelleyici kontrol ve çalışma belleği olarak adlandırılmıştır. 22 Maddeden oluşan üç faktörlü öz düzenleme ölçeğinin geçerliğini test etmek için uygulanan DFA analizi sonucunda uyum indexlerinin yeterli düzeyde olduğu tespit edilmiştir $(\chi 2 / \mathrm{sd}=1.28, \mathrm{RMSEA}=.046, \mathrm{SRMR}=.07)$. Ölçeğin ölçüt geçerliği için çocuk davranış değerlendirme ölçeği kullanılmıştır. Çocuk Davranış Değerlendirme ölçeği Bronson, Goodson, Layzer ve Love (1990) tarafindan geliştirilmiş ve Sezgin ve Demiriz (2016) tarafından Türkçe’ye uyarlanmıştır. Türkçeye uyarlanan ölçek formunun kullanıldığ1 ölçüt geçerliği sonucunda eş zaman ve yordama geçerliğinin anlamlı olduğu tespit edilmiştir.

Veri toplama aracının madde analizine göre yapılan istatistiki işlemlere göre madde toplam korelasyon değeri .41 ile .77 arasında değişmektedir. Maddelerin \%27’lik üst ve alt grup arasında 
madde ayırt edicilik değerlerine göre bağımsız t testi sonuçlarına göre ayırt edici oldukları tespit edilmiştir $(7.36<\mathrm{t}<17.61, \mathrm{sd}=169, \mathrm{p}<.01)$. Ölçme aracına ait iç tutarlık katsayısı Cronbach Alpha incelenmiştir. Ölçeğin toplam boyutuna ait iç tutarlık katsayıs1 .94 olduğu tespit edilmiştir. Ölçeğin faktörlerinin iç tutarlık değerleri, dikkat .91, engelleyici kontrol .91 ve çalışma belleğinin .87 olduğu belirlenmiştir. Bu sonuçlar ışığında veri toplama aracının geçerli ve güvenilir olduğu anlaşılmaktadır.

\section{Veri toplama aracının geçerliği ve güvenirliği}

Bu araştırmada “4-6 Yaş Cocuklarna Yönelik Öz düzenleme Becerileri Ölçeği (Öğretmen formu)' na ait geçerlik ve güvenirlik değerlerine aşağıda yer verilmiştir. Araştırmaya katılan çocuklardan oluşan veri setine doğrulayıcı faktör analizi uygulanarak yapısal geçerliği test edilmiştir. Veri toplama aracına ait standart tahmin değerleri Şekil 2'dedir.

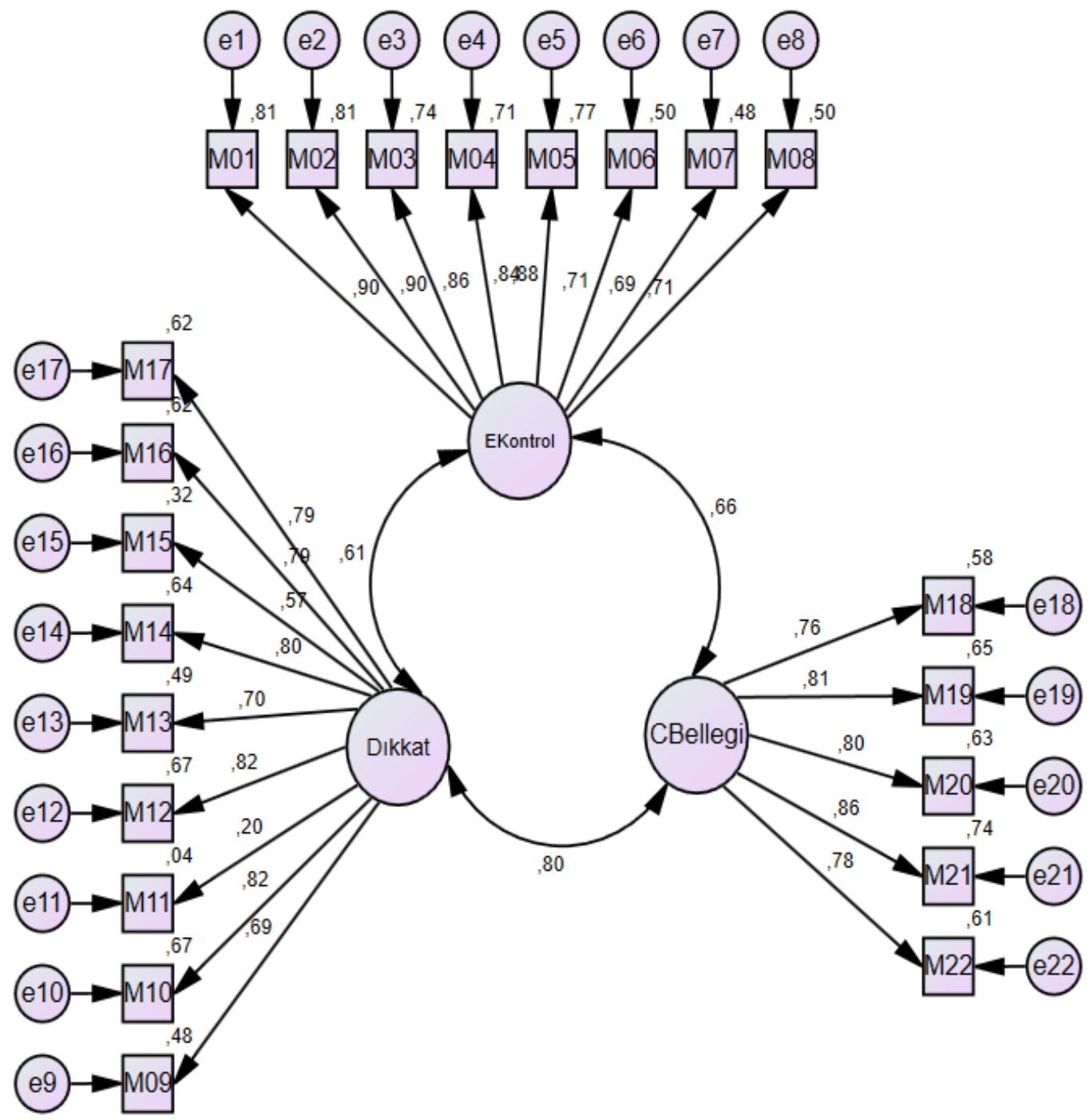

Şekil 2. Veri toplama aracına ait standart tahmin değeri 
Şekil 2'de faktörler altında yer alan maddelerin anlamlı farlılığını tespit etmek için t değerleri incelenmiştir. Şekil 2' ye göre ölçekteki maddelerin t değerleri 10.225 ile 16.085 arasındadır. Maddelerin $t$ değerleri her bir madde için $(\mathrm{p}<.01)$ anlamlı düzeyde farklılık göstermektedir.

Araştırmada DFA sonuçlarını değerlendirmek için belirlenen uyum indexleri şunlardır: Ki kare değerinin serbestlik derecesine oranı $(\chi 2 / s d)$, yaklaşık hataların ortalama karekökü (Root Mean Square Error of Approximation-RMSEA), normlaştırılmış uyum indeksi (Normed Fit Index-NFI), karşılaştırılmış uyum indexi (Comparative Fit Index-CFI), uyum iyiliği indexi (Goodness of Fit Index-GFI), düzeltilmiş uyum iyiliği indexi (Adjustment Goodness of Fit Index-AGFI), artan uyum indexi (Incremental Fit Index-IFI) (Tabachnick ve Fidell, 2013). Öz düzenleme becerileri ölçeğine ait uyum düzeyi değerleri $\left[\chi^{2}=939.831 ;(\mathrm{df}=202, \mathrm{p}<.001) ; \chi 2 / \mathrm{sd}=4.653 ; \mathrm{RMSEA}=.068\right.$, $\mathrm{NFI}=.904, \mathrm{CFI}=.912, \mathrm{GFI}=.905, \mathrm{AGFI}=.923$, IFI=.935] incelendiğinde $\chi 2 / \mathrm{sd}$ (Anderson ve Gerbing, 1984; Kline,2016), RMSEA (Jöreskog ve Sörbom,1993; Hu ve Bentler, 1998), NFI (Hu ve Bentler, 1998; Tabachnick ve Fidell, 2013), CFI (Tabachnick ve Fidell, 2013), GFI (Shevlin ve Miles, 1998; Hooper ve diğerleri., 2008) ve IFI (Marsh ve Hau, 1996) değerlerinin alan yazına göre iyi uyum değer aralığında olduğu tespit edilmiştir.

Veri toplama aracına ait güvenirlik değerlerini incelemek için Cronbach'ın Alpha iç tutarlık katsayısı kullanılmıştır. Çalışma belleğinin iç tutarlık katsayısı .94'tür. Dikkat faktörünün iç tutarlık katsayısı .78 'dir. Çalışma belleğinin iç tutarlık katsayısı .90 'dır. Veri toplama aracının iç tutarlık katsayısı .89'dur. Bu bağlamda veri toplama aracının güvenilir olduğu belirlenmiştir.

\section{Veri Analizi}

\section{Varsayımlarin incelenmesi}

Veri seti analiz edilmeden önce eksik verilerin tamamlanması, örneklemin büyüklügü, değişkenlerin normallik ve doğrusallık değerleri incelenmiştir ( Tabachnick ve Fidell, 2013 ). Veri setinde hatalı ya da eksik veri olmadığ1 tespit edilmiştir. Örneklem büyüklüğü için veri setinin $\left(\mathrm{x}^{2} / \mathrm{sd}\right)$ oran uygunluğu ölçüt olarak alınmıştır. Bu ölçütün $(3<4.65 \leq 5)$ kabul edilebilir düzeyde karşlandığ1 tespit edilmiştir (Anderson ve Gerbing, 1984; Kline, 2016). Tek değişkenli normallik değerleri incelemesi sonucunda basıklık ve çarpıklık katsayılarının -1 ile +1 arasında değerler alarak normallik varsayımını karşıladığı belirlenmiştir. Modeli oluşturan değişkenlerin ayrı ayrı saçılım grafikleri üzerinden doğrusallık varsayımı incelendiğinde doğrusallık varsayımının karşılandığı tespit edilmiştir. Korelasyon matrisinin çoklu bağlanma sorunu olmadığı ve tekillik kontrollerinin anlamlı değerler aralığında olduğu tespit edilmiştir. Çoklu doğrusallık problemini analiz etmek için Varyans 
Enflasyon Faktörü (VIF) değerinin 10 dan küçük olduğu ve Tolerans (T) değerinin sıfirdan farklı olduğu ve Koşullu Endeks (CI) değerinin 30'dan düşük olduğu tespit edilmiştir (Menard, 1995; Paul,2007; Tabachnick ve Fidell, 2013). Bu bağlamda veri setinin çoklu doğrusallığa neden olmayan verilerden oluştuğu anlaşılmaktadır.

\section{Analiz metodu}

Araştırmada çalışma belleği ve engelleyici kontrol arasında aracı değişken olan dikkatin aracı değişkenliğinin anlamlı olup olmadığını ve hipotezleri tespit etmek için gözlenen değişkenlerle aracılı yapısal eşitlik modellemesi kurulmuştur. Yapısal Eşitlik Modellemesi (YEM) analizi, değişkenler arasında neden sonuç ilişkisine dayalı regresyon modelidir (Kline, 2016). YEM analizi şekil 1'de araştırma için karma hipotezlerden önerilen modelin değişkenleri arasında neden sonuç ilişkisinin anlamlı düzeyde olup olmadığını tespit etmeyi sağlamaktadır. Araştırmada önerilen model, yol analizi (path analysis) ile elde edilen değerlere göre incelenmiştir. Önerilen modelde aracı değissken dikkatin anlamlı bir değissken olup olmadığını tespit etmek için bootstrap yöntemi kullanılmıştır. Bootstrap yöntemi, Baron ve Kenny'nin geleneksel aracıllk testinden ve Sobel araacllık testinden daha güvenilir sonuçlar verdiği savunulmaktadır (Baron ve Kenny, 1986; Gürbüz, 2019; Hayes, 2018). Bootsrtrap yöntemi ile arac1lık testi analizinde, 5000 yeniden örnekleme ve güven aralığının \%95 olarak belirlenmiştir. Güven aralığı 0 değerini kapsamayan değerlerin aracı değişken olduğu savunulmaktadır. Bu bağlamda araştırmanın bulgularında öncelikle basit etki modeli sonra araştırmanın önerilen aracı etki modeli yer verilerek, aracılık değişkeninin etkililiği ve anlamlılı̆̆1 tespit edilmeye çalışılmıştır. Araştırmada DFA ve yol analizi için AMOS 23, veri seti girişi, test istatistiği ve korelasyon değerleri için SPSS 21 programı kullanılmıştır.

\section{BULGULAR}

Araştırmanın hipotezlerine yönelik bulgulardan önce araştırmanın değişkenleri arasındaki ilişkiler ve betimsel istatistik sonuçlarına yer verilmiştir. Hipotezleri test etmek için basit etki modeli ve aracı etki modelinin yol analizi değerleri sırasıyla açıklanmıştır.

Araştırmanın modelini oluşturan değişkenler arasındaki ilişki ve betimsel istatistikler sonuçları tablo 1'dedir.

Tablo 1. Değişkenler arasındaki korelasyon, ortalama, standart sapma, basıklık ve çarpıklık sonuçları

\begin{tabular}{lccccccc}
\hline Değişkenler & 1 & 2 & 3 & $\mathrm{X}$ & $\mathrm{SS}$ & Skewness & Kurtosis \\
\hline 1.Çalışma Belleği & 1 & & & 20.94 & 3.46 & -.645 & .448 \\
\hline 2.Dikkat & $.843^{* *}$ & 1 & & 36.27 & 5.96 & -.631 & .348 \\
\hline 3. Engelleyici Kontrol & $.747^{* *}$ & $.679^{* *}$ & 1 & 32,00 & 5.50 & -.805 & .577 \\
\hline
\end{tabular}

** korelasyon değerleri $\mathrm{p}<.01$ düzeyinde anlamlı farklılık göstermektedir. 
Tablo 1'e göre, çalışma belleği, dikkat ve engelleyici kontrol arasındaki korelasyonun $(\mathrm{p}<.01)$ düzeyinde anlamlı olduğu tespit edilmiştir. Korelasyon değerlerine göre, değişkenler arasında en yüksek ilişki çalışma belleği ve dikkat arasındadır. Değisskenlerin normal dağılımı için gösterge olan basıklık ve çarpıklık değerlerinin ise -1 ile +1 arasında değerler aldığı belirlenmiştir. Aracı etki modelinde (bknz Şekil 1) yer alan dikkatin çalışma belleği ve engelleyici kontrol arasında aracıllk yapıp yapmadığını tespit etmek için öncelikle basit etki modeli (bknz Şekil 3 ) incelenmiştir.

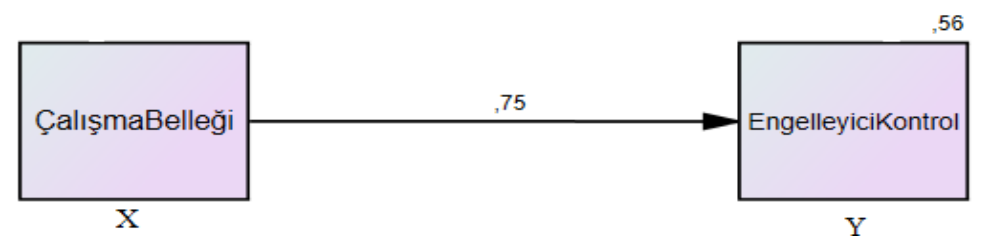

Şekil 3. Basit etki modelinin standart tahmin değeri

Çalışma belleği ve engelleyici kontrol arasındaki ilişkiye ait basit etki modeli path analizi sonuçlarına tablo 2'de yer verilmiştir.

Tablo 2. Basit Etki Modeli değişken yol analizi sonuçları

\begin{tabular}{lcccc}
\hline Tahmini Değişken & \multicolumn{4}{c}{ Sonuç Değişkeni } \\
\cline { 2 - 5 } & \multicolumn{4}{c}{ Engelleyici Kontrol $(\mathrm{Y})$} \\
\cline { 2 - 5 } & $(\beta)$ & $\mathrm{SH}$ & $\mathrm{t}$ & $\mathrm{p}$ \\
\hline Çalışma Belleği $(\mathrm{X})$ & .747 & .074 & 15.975 & .000 \\
\hline
\end{tabular}

Tablo 2'ye göre, çalışma belleği $(\beta=.747 ; t=15.975 ; \mathrm{p}<.01)$ engelleyici kontrolü doğrudan ve pozitif yönde etkilemektedir. Basit etki modelinde çalışma belleği engelleyici kontrole olan etkisi $\left(\mathrm{R}^{2}=.56\right)$. Bu bağlamda çalışma belleği engelleyici kontrol üzerinden varyansın \% 56'sını açıklamaktadır.

Basit etki modeline $(\mathrm{X} \rightarrow \mathrm{Y})$ aracı değişken $(\mathrm{M})$ eklenmesi sonrası oluşan aracı etki modeline ait AMOS çıtıtısı Şekil 4’tedir.

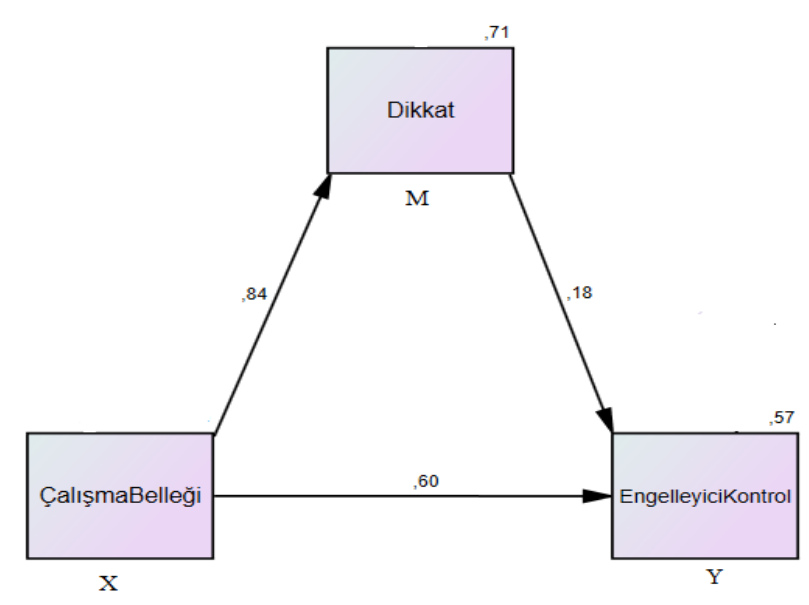

Şekil 4. Aracı etki modelinin standart tahmin değeri 
Çalışma belleği, dikkat ve engelleyici kontrol arasında kurulan $\mathrm{H}_{1}, \mathrm{H}_{2} \mathrm{ve}_{3}$ hipotezlerine ait bulgular tablo 3'tedir.

Tablo 3. Aracı etki modeli değişken yol analizi sonuçları

\begin{tabular}{lccccccccc}
\hline \multirow{2}{*}{ Tahmin Değişkenleri } & \multicolumn{1}{c}{ Sonuç Değişkenleri } & Hipotez \\
\cline { 2 - 11 } & \multicolumn{3}{c}{ Engelleyici Kontrol $(\mathrm{Y})$} & \multicolumn{3}{c}{ Dikkat $(\mathrm{M})$} \\
\cline { 2 - 11 } & $(\beta)$ & $\mathrm{SH}$ & $\mathrm{t}$ & $\mathrm{p}$ & $(\beta)$ & $\mathrm{SH}$ & $\mathrm{t}$ & $\mathrm{p}$ & \\
\hline Çalışma Belleği $(\mathrm{X})$ & .604 & .137 & 7.016 & .000 & .843 & .065 & 22.250 & .000 & $\mathrm{H}_{1} / \mathrm{H}_{2}$ \\
\hline Dikkat $(\mathrm{M})$ & .182 & .038 & 3.745 & .000 & - & - & - & - & $\mathrm{H}_{3}$ \\
\hline
\end{tabular}

Tablo 3'e göre, çalışma belleği $(\beta=.604 ; \mathrm{t}=7.016 ; \mathrm{p}<$.01) engelleyici kontrolü doğrudan ve pozitif yönde etkilemektedir. Bu bağlamda, $H_{1}$ kabul edilmiştir. Çalışma belleği $\quad(\beta=.843 ; \mathrm{t}=$ 22.250; $\mathrm{p}<$.01) dikkati doğrudan ve pozitif yönde etkilemektedir. Bu sonuca göre, $\mathrm{H}_{2}$ hipotezi kabul edilmektedir. Dikkat $(\beta=.182 ; \mathrm{t}=3.745 ; \mathrm{p}<.01)$ engelleyici kontrolü doğrudan ve pozitif yönde etkilemektedir. Bu sonuca göre, $\mathrm{H}_{3}$ hipotezi kabul edilmiştir.

Modeldeki değişkenler (bknz şekil 4), engelleyici kontrolü $\left(R^{2}=.57\right.$ ) varyansın \% 57'sini, dikkat $\left(\mathrm{R}^{2}=.71\right)$ varyansın yüzde 71'ini açıklamaktadır.

Aracı etki modelinde (bknz Şekil 4) dikkatin anlamlı aracı değişken olduğunu tespit etmek için bootstrap tekniği ile aracılık etki analizi yapılarak $\mathrm{H}_{4}$ ait bulgulara tablo 4 'te yer verilmiştir.

Tablo 4. Standardize dolaylı etki sonuçları

\begin{tabular}{lccccc}
\hline Standardize & \multicolumn{5}{c}{ Çalışma Belleği } \\
\cline { 2 - 6 } Dolaylı Etki & $(\beta)$ & Alt Güven Aralığ1 & Üst Güven Aralı̆̆1 & $\mathrm{p}$ & Hipotez \\
\hline Engelleyici Kontrol & .096 & .039 & .281 & .000 & $\mathrm{H}_{4}$ \\
\hline
\end{tabular}

Bootstrap testi sonuçlarına göre (bknz Tablo 4), çalışma belleğinin $(\beta=.096 ; \mathrm{p}<.01 ; \% 95$ GA $[0.039,0.281])$ dikkat vasıtasıyla engelleyici kontrol üzerinde dolaylı etkisinin anlamlı olduğu tespit edilmiştir. Bu noktadan hareketle basit etki modeli (şekil 3) ile aracı etki modeli (şekil4) karşılaştırıldığında, aracı etki modelinde çalışma belleği ve engelleyici kontrol arasında ilişki azalmış olup, anlamlı farklılık ortadan kalkmadığı saptanmıştır. Bu nedenle dikkatin çalışma belleği ve engelleyici kontrol arasında kısmi aracı etkiye sahip olduğu anlaşılmaktadır. Bu bağlamda $\mathrm{H}_{4}$ kabul edilmiştir.

\section{SONUÇ}

Araştırmanın sonucunda çalışma belleği, dikkat ve engelleyici kontrol bir birleriyle anlamlı düzeyde ilişkilidir. Dikkat ve engelleyici kontrol becerisi çalışma belleğinden doğrudan ve olumlu yönde etkilenmektedir. Dikkat, engelleyici kontrol becerisini doğrudan ve olumlu yönde etkilemektedir. Çalışma belleği ve engelleyici kontrol arasında dikkatin kısmi aracılık etkisi olduğu tespit edilmiştir. 
Araştırmanın sonuçlarına göre çalışma belleği, dikkat ve engelleyici kontrol becerileri birbirinden bağımsız bilişsel ve davranışsal becerilere ait özellikleri taşımasına rağmen etkileşimli etkisi öz düzenleme becerilerinin işlevsel özelliklerini ortaya çıkarmaktadır. Öz düzenleme becerileri arasındaki ilişkisi incelendiğinde, çalışma belleği ile engelleyici kontrol becerisinin etkileşiminde dikkatin kısmi aracı rolü, öz düzenleme becerilerinin işlevlerini açıklanamasına yönelik önemli bir sonuçtur.

\section{TARTIŞMA}

$\mathrm{Bu}$ araştırmanın amac1, 60-72 aylık okul öncesi dönem çocuklarında dikkat, çalışma belleği ve engelleyici kontrol becerileri arasındaki ilişki ve çalışma belleği ile engelleyici kontrol arasında dikkatin aracı değişken rolünün incelenmesidir. Konuya ilişkin alanyazın temel alınarak bir model oluşturulmuş ve 4 hipotez ile model test edilmiştir.

Yürütücü işlevler ve öz düzenlenme becerileri olarak ele alınan çalışma belleği, dikkat ve engelleyici kontrolün, erken çocukluk yıllarında desteklenmesi durumunda çocukların bilişsel, sosyal ve akademik becerilerinde önemli katkı sağladığı araştırmalardan anlaşılmaktadır (Berg, 2008; Blair ve Razza, 2007; Blair, Knipe ve Gamson, 2008; Blair ve Raver, 2015; Altemeier, Abbott ve Berninger, 2008; Walcott, Scheemaker ve Bielski, 2010). Çocukların bilişsel, sosyal ve akademik becerilerini desteklemek için son derece önemli olan bu değişkenlerin arasındaki ilişki alanyazın 1şığında tartışılmıştır.

Dikkat, çalışma belleği ve engelleyici kontrol bir biriyle ilişkili olup, bir birilerini nasıl etkilediği üzerine tartışmalar kuramsal boyutta ele alınıp ilgili araştırmalar ışığında incelenmiştir. Araştırmanın birinci hipotezinin sonucuna göre çalışma belleği engelleyici kontrolü doğrudan ve olumlu yönde etkilemektedir. Nitekim Bryce ve Whitebread'ın (2012) yaptıkları çalısmada, bellek ve dürtü kontrolü arasında ilişki olduğu savunulmaktadır. İvrendi ve Erol (2018) tarafindan yapılan araştırmada çalışma belleği ve engelleyici kontrol arasında anlamlı ilişki olduğu tespit edilmiştir. Swanson ve Beebe-Frankenberger (2004) tarafindan yapılan araştırmada, eski bilgilerle yeni bilgilerin birleştirilmesi üzerinde öğrenmeye destek olmada çalışma belleği sınırlı çocukların, güçlük çektiği tespit edilmiştir.

Passolunghi ve Siegel, (2001) tarafindan yapılan araştırmada, aritmetik problem çözme yetersizliği olan çocukların kısa süreli bellek, çalışma belleği ve engelleyici kontrol becerileri arasındaki ilişki incelenmiştir. Araştırmada beceriler arasındaki ilişki aritmetik problem çözme yetersizliği olan çocuklarla ( $n=23)$, iyi düzeyde problem çözen çocukların $(n=26)$ kısa süreli bellek, çalışma belleği 
ve engelleyici kontrol becerileri karşılaştırılmıştır. Araştırmanın sonuçlarına göre, aritmetik problemleri çözmede zayıf olan çocukların belleklerine hedeflerinde olmayan ve problemlerle ilgili olmayan bilgilerin erişilebilirliğini azaltma yeteneklerinin zayıf olduğu tespit edilmiştir. Aritmetik problemleri çözmede yetersiz olan çocukların engelleyici kontrol becerilerinde genel bir eksiklik olduğu belirlenmiştir. Çalışma belleği potansiyeli düşük olan çocukların belleklerine daha fazla uyaran girdiği ve çalışma belleklerindeki puanların düşük olduğu tespit edilmiştir.

Bull, Espy ve Wiebe (2008) tarafından yapılan araştırmada, okul öncesi dönem çocukların kısa süreli bellek, çalıma belleği ve yürütücü işlevlere yönelik ölçümlerin, çocuğun ilkokul yıllarında akademik başarıda yeterliğini yordayıp yordamadığı incelenmiştir. Çocukların anaokulu yıllarından başlanarak bilişsel, matematik ve erken okuryazarlıklarına ait ölçümler ilkokula başladığı günden üçüncü sınıfa kadar takip edilmiştir. Büyüme eğrisi analizlerine göre, yürütücü işlevler matematik ve erken okuryazarlık becerisinin çocukların ilkokulun ilk üç yllında etkisini sürdürdüğgu tespit edilmiştir. Görsel kısa süreli ve çalışma belleği, çocukların takip edilen her okul döneminde matematik becerilerinin anlamlı yordayıcısı olduğu belirlenmiştir. Bu bağlamda Blair ve Razza (2007), engelleyici kontrol becerisi gelişmiş çocukların okul öncesi dönem sonrası matematikte başarılı olma nedeni olarak çalışma belleğinin gelişmiş olmasını savunmaktadır. Berg (2008) tarafından yapılan araştırmada ise çalışma belleği ve matematik becerileri arasında yüksek ilişki olduğu tespit edilmiştir. Bu araştırmalar ışığında, çocukların akademik başarıları üzerinden çalışma belleği ve engelleyici kontrol arasındaki ilişkinin anlamlı olduğu söylenebilir.

Araştırmanın ikinci hipotezinin sonucuna göre, çalışma belleği dikkati doğrudan ve olumlu yönde etkilemektedir. Bu bağlamda çalışma belleğinin gelişiminin desteklenmesi dikkatin gelişimini olumlu yönde etkilediği söylenebilir.

Çalışma belleği ve dikkat arasında doğrudan ilişki olduğu alan yazından (Swayze ve Dexter, 2017; Parker, 2001; McCabe ve diğerleri 2010; Shipstead. Martin ve Nespodzany, 2019; İvrendi ve Erol, 2018; Shipstead, Lindsey, Marshall ve Engle, 2014) tespit edilmiştir. Beck, Hanson, Puffenberger, Benninger ve Benninger (2010) tarafından yapılan araştırmaya göre, DEHB’li çocuklara yönelik hazırlanan çalışma belleği eğitim programı, 5 hafta boyunca 52 çocuk ve ergene uygulanmıştır. Uygulama sonucunda DEHB'li çocuklarda çalssma belleği, yürütücü işlevler ve DEHB semptomlarının ölçümlerine göre olumlu yönde gelişim tespit edilmiştir. Araştırmanın sonuçlarına göre Beck ve diğerleri (2010) DEHB’li çocukların DEHB semptonlarının azalması için çalışma belleğinin geliştirilmesini savunmaktadır. 
Klingberg, Forssberg ve Westerberg (2002) tarafindan yapılan araştırmada, dikkat eksikliği hiperaktivite bozukluluğu (DEHB) tanısı konulmuş 14 çocuk ile çalışma belleği örtük programının DEHB üzerine etkisi incelenmiştir. DEHB olan çocuklar için geliştirilen çalışma belleği eğitim programı, bilgisayar destekli uygulamalar ile çocuklara geri bildirim ve olumlu pekiştireçler verilerek çalışma belleği görevlerinin tekrarlanma performanslarını artırmayı amaçlamaktadır. Deney grubunda bulunan çocuklarla $(n=7)$ kontrol grubunda bulunan çocukların $(n=7)$ karşılaştırılması sonucunda, eğitim programının deney grubundaki çocuklarda prefrontal işlevsellikle ilgili görevlerde artma meydana geldiğini ve çocukların motor becerilerini düzenlemede önemli etkiye sahip olduğu tespit edilmiştir. Dikkatin gelişiminin çalışma belleği ile olan ilişkisi çocukların akademik başarısıyla ilişkisi üzerinden incelenmiştir. Duncan ve diğerleri (2007) tarafindan yapılan araştırmada dikkat becerisinin gelişimi okuma ve matematik becerilerinin gelişimine katkı sunmaktadır. Matematik ve okuma becerileri üzerinde çocukların dikkat becerileriyle ilgili olduğu alanyazında savunan araştırmalar ( Blair, Knipe ve Gamson, 2008; Blair ve Raver, 2015; Altemeier, Abbott ve Berninger, 2008; Walcott, Scheemaker ve Bielski, 2010) mevcuttur.

Dikkat becerisini kontrol edemeyen çocuklarda engelleyici kontrol davranışlarını düzenleme problemleri gözlemlenmektedir (Meltzer ve Krishnan, 2007; Shanahan, Pennington ve Willcutt, 2008). Araştırmanın üçüncü hipotezinin sonucuna göre dikkat becerisini gelişimi engelleyici kontrolün gelişimini sağlamaktadır. Bu noktadan hareketle çocukların dikkat kontrollerinin sağlanmas1, Macdonald, Beauchamp, Crigan ve Anderson, (2014) göre, engelleyici kontrol davranışı olan çocukların iç tepisel dürtülerini kontrol etme ve oto kontrolü artırıp, haz uyandıran davranışlarını engelleyebilmeyi sağlayacaktır. Nitekim engelleyici kontrol becerisi çocukların, bilişsel, sosyal ve akademik gelişimleri ile ilişkilidir (Ertürk Kara, Güler Yıldız, Fındık, 2018). Sweeney, Rosano, Berman ve Luna (2001) tarafından yapılan araştırmaya, 28 genç yetişkin ve 20 sağlıklı yaşlı katılımıştır. Aaştırmacılar genç ve yaşlılardan aldıkları ölçümleri karşılaştırarak dikkatin engelleyici kontrol üzerindeki etkisini araştırmıştır. Genç ve yaşlı katılımcılanın çalışma belleği görevinde, yaşlı bireylerin gençler kadar iyi performans sergilediği tespit edimiştir. Çalışmanın sonucunda gençlerin normal yaşlanma sürecinde istemli engelleyici kontrol becerilerinin azaldığı, ancak uzamsal çalışan belleğin kodlama ve geri çağırma işlevlerinde önemli bir değişim tespit edilmemiştir.

Sonuga-Barke, Dalen, Daley, Remington (2002) tarafindan yapılan araştırma okul öncesi dönem çocuklarının engelleyici kontrol ile DEHB belirtileri arasındaki ilişki incelenmiştir. Araştırmanın sonuçlarına göre, DEHB ile engelleyici kontrol arasında negatif anlamlı ilişki tespit edilmiştir ( $\mathrm{r}=$ .25). DEHB ile engelleyici kontrol arasındaki bu ilişki Barkley'in (1997), DEHB'nin okul öncesi 
dönemde engelleyici kontrol becerisindeki eksikliklere neden olduğu görüşünü desteklendiğine dair kanıt sağlamaktadır

Bu nedenle çocukların dikkat gelişiminin desteklenmesi engelleyici kontrol becerisini geliştirecek, dolayısıyla çocukların ilerleyen yıllarda bilişsel, sosyal ve akademik gelişiminde olumlu bir gelecek sağlayacaktır. Ayrıca engelleyici kontrol becerisi gelişemeyen çocuklarda, dikkat toplama becerisi sorunuyla birlikte fiziksel sağlık, madde bağımlılığı suç oluşturan davranışlar gözlemlenebilir (Moffitt ve diğerleri, 2011).

Araştırmanın bulgularına göre, çalışma belleği ve dikkat engelleyici kontrolü doğrudan ve olumlu yönde etkilemektedir. Ancak dikkat çalışma belleği ve engelleyici kontrol arasında aracı etkiye neden olmaktadır. Dikkat ve çalışma belleği arasındaki ilişki (Awh ve diğerleri, 1998; Chun, 2011; Gazzaley ve Nobre, 2012; Kiyonaga ve Egner, 2014; Oberauer, 2009; Olivers, 2008) birçok araştırma tarafindan tespit edilmiştir. Dikkatin çalışma belleği ve engelleyici kontrol arasında anlamlı aracı değişken olması, Oberauer’ a (2019) göre, çalışma belleği üzerinde tutulan bilginin dikkatin sürdürülmesi sonucu davranışı düzenleyerek engelleyici kontrolün düzenlenmesini sağlamaktadır. Robert ve diğerleri, (2009) tarafından yapılan araştırmanın sonuçlarına göre bireyin yaşamı boyunca dikkat, engelleyici kontrol becerisi üzerinde etkilidir. Bu noktadan hareketle çocukların çalışma belleği ve dikkat gelişimlerinin desteklenmesi engelleyici kontrol davranışlarının, gelişimine olumlu etkisi olduğu söylenebilir. Bu bağlamda çalışma belleğinin engelleyici kontrol üzerinde etkisinde dikkatin aracı değişken olarak rol oynaması öz düzenleme becerileri arasındaki ilişkinin farklı yönlerini de ortaya çıkarmaktadır.

Kar ve Kenderla, (2017) göre, erken çocukluk yıllarında çocukların çalışma belleği ve dikkat becerilerin desteklenmesini ayrı ayrı değerlendirildiğinde, çalışma belleği bilgilerinde hafızada tutulması ve kullanılmasında etkindir. Dikkat uyaranların takip edilmesi ve uyaranların seçilmesi gibi görevi vardır. Halbuki bu iki bilişsel öğenin etkileşimi ayrı ayrı üstlenmiş oldukları bilişsel görevlerin üzerindedir. Çalışma belleği ve dikkatin etkileşimi sonucunda bilişsel, duyuşsal ve davranışsal süreçlerde ayrı ayrı işlevsel özellikleri ortaya çıkmaktadır. Çocuklarda problem çözme, karar verme, engelleyici kontrol, dil ve sosyal becerilerin gelişiminde çalışma belleği ve dikkatin etkileşimi söz konusudur. Çalışma belleği ve dikkatin üst düzey bilişsel becerileri tetiklenmesinde erken çocukluk dönemi eğitiminin kritik etkisi vardır. Çocukların ilerleyen yıllarda bilişsel, sosyal ve duygusal, motor gelişimleri ve akademik becerilerinde gözlemlenebilir farklılık erken çocukluk yıllarında çalışma belleğinin ve dikkatin desteklenmesi ile ilişkilidir. 
Gözüm, Coşkun ve İpek’e (2019) göre, öğretmenler yürütücü işlevlerinin desteklenmesi için çocukların sınıf içi etkinliklerde yaptıkları hataları kontrol edebilecek bir eğitim ortamı planlamalıdır. Çocukların katıldıkları etkinliklerde ne yapacaklanına karar vermeleri, etkinlikleri sürdürmeleri, etkinliği tamamlamalarına engel olan durumları belirlemeleri ve belirledikleri durumlar üzerinde düşünerek getirdikleri çözümler doğrultusunda etkinliklerini devam ettirmeleri belirli bir amaca odaklandıklarının göstergesidir. Çocukların odaklanabilecekleri etkinlikler ilgi ve gereksinimlerine yönelik olabilir. Bu nedenle, okul öncesi dönem çocukları için doğal gereksinim ve ilgi kaynağı olan oyunun yürütücü işlevlerin gelişiminde kritik önemi vardır. Çocukların hem duyuşsal hem de bilişsel becerilerini düzenlemelerini sağlayan yürütücü işlevlerinin oyun içerisinde gömülü olduğu savunulmaktadir.

Çocuklarda dikkat, çalışma belleği ve engelleyici kontrolün yeni bir oyun öğrenirken nasıl etkin olduğunuı açıklayan Raver ve Blair (2016) aynı zamanda eğitimcilere de uygulamalara yönelik ipuçları vermiştir. Çocuklar yeni bir oyun oynamayı öğrenirken, oyunun kurallarını öğrenmeleri gerekir. Oyunun kullarından akılda kalan bilgi çalışma belleğini gösterir. Oyun içerisinde oyunun önemli yerlerine çocuklar odaklanarak dikkatlerini esnek bir şekilde kullanarak diğer oyuncuların stratejilerinin farkına varır. Oyun içerisinde çocuk kendi sırasını beklerken iç tepisel olarak kendini kontrol ederek engelleyici kontrolünü geliştirir. Bu davranış dizisi tekrarlayan oyunlarla pekiştirilerek gelişir ve çocukların yaşları büyükçe gelişen beceriler bütünleşir. Çocukların ilerleyen yıllarından okuryazarlık ve matematik becerilerine çalışma belleği, dikkat ve engelleyici kontrolün olumlu etkileri olacaktır. Bu noktadan hareketle erken çocukluk yıllarında çocukların dikkat, çalışma belleği ve engelleyici kontrol becerilerinin desteklenmesi için eğitimcilerin oyun temelli etkinliklerin planlanması beklenmektedir.

\section{SINIRLILIKLAR ve ÖNERİLER}

$\mathrm{Bu}$ bölümde araştırma sürecine ait sınırllıklara ve gelecekte yapılacak araştırmalara yönelik önerilerde bulunulmuştur.

Araştırmanın verileri, öğretmenler tarafindan çocukların gözlemlenmesi sonucu doldurulan veri toplama aracıyla toplanmıştır. Gözlemcilerin gözlem sürecinde etkisi araştırmanın sınırlılıkları arasında sayılabilir. Araştırmadaki değişkenler, araştırmanın amacı doğrultusunda çocukların doğrudan gözlemlenebileceği görevler üzerinden nitel, nicel ya da karma araştırma yöntemlerine göre test edilebilir. 
Araştırmanın sonuçlarına göre dikkat, çalışma belleği ve engelleyici kontrol becerileri arasında ilişki tespit edilmiştir. Ancak alanyazın taramasına göre çalışma belleği ve dikkat bir biriyle yakın ilişkilidir. Bu bağlamda çalışma belleği, dikkat ve engelleyici kontrol arasında, aracı değişken olarak öneren modeller üzernden araştırmalar yapılabilir. Araştırmada önerilen model farklı yaş guruplarında bulunan çocuklara uygulanarak; çalışma belleği, dikkat ve engelleyici kontrolden oluşan ilişki düzeyi yaş değişkenine göre karşılaştırılabilir. Alanyazın taramasında çalışma belleği, dikkat ve engelleyici kontolün, bilişsel, dil, sosyal-duygusal, motor ve akademik becerileriyle de ilişkili olduğu tespit edilmiştir. Gelecekte yapılacak araştırmalarda çalışma belleği, dikkat ve engelleyici kontrol değişkenleriyle birlikte bilişsel, dil, sosyal-duygusal, motor ve akademik becerileri arasındaki ilişkiyi keşfetmeye ve uygulamaya yönelik araştırmalar yapılabilir.

\section{KAYNAKÇA}

Adams, A. M., Bourke, L., \& Willis, C. (1999). Working memory and spoken language comprehension in young children. International Journal of Psychology, 34, 364-373.

Altemeier, L.E., Abbott, R.D., \& Berninger, V.W. (2008). Executive functions for reading and writing in typical literacy development and dyslexia. Journal of Clinical and Experimental Neuropsychology, 30, 588-606.

Anderson, J. C., \& Gerbing, D. W. (1984). The effect of sampling error on convergence, improper solutions, and goodness-of-fit indices for maximum likelihood confirmatory factor analysis. Psychometrika, 49(2), 155-173. https://doi.org/10.1007/BF02294170

Anderson, J.R. (2005). Cognitive psychology and its implications. 6th. New York: Worth.

Awh, E., Jonides, J., \& Reuter Lorenz, P. A. (1998). Rehearsal in spatial working memory. Journal of Experimental Psychology: Human Perception and Performance, 24(3), 780- 790.

Baddeley, A. D. (1986). Working memory. New York: Oxford University Press.

Barkley, R. A. (1997). Behavioural inhibition, sustained attention, and executive functions: Constructing a unifying theory of ADHD. Psychological Bulletin, 121, 65-94.

Baron, R. M., \&Kenny, D. A. (1986). The moderator-mediator variable distinction in social psychological research: Conceptual, strategic, and statistical considerations. Journal of Personality and Social Psychology, 51(6), 1173-1182

Baumeister, R. F., \& Vohs, K. D. (Eds.). (2004). Handbook of self-regulation: Research, theory, and applications. New York, NY: Guilford Press.

Beck, S. J., Hanson, C. A., Puffenberger, S. S., Benninger, K. L., \& Benninger, W. B. (2010). A controlled trial of working memory training for children and adolescents with ADHD. Journal of Clinical Child \& Adolescents Psychology, 39 (6), 825-836.

Beck, S. J., Hanson, C. A., Puffenberger, S. S., Benninger, K. L., \& Benninger, W. B. (2010). A controlled trial of working memory training for children and adolescents with ADHD. Journal of clinical child and adolescent psychology : the official journal for the Society of Clinical Child and Adolescent Psychology, American Psychological Association, Division 53, 39(6), 825-836. 
Bee, H. ve Boyd, D. (2009). Bilisssel Gelişim. Coouk Gelişim Psikolojisi içinde (s.309-371)., (Çev. O. Gündüz ). İstanbul: Kaknüs Yayınları.

Berg, D. H. (2008). Working memory and arithmetic calculation in children: The contributory roles of processing speed, short-term memory, and reading. Journal of Experimental Child Psychology, 99, 288-308

Best, J. R., \& Miller, P. H. (2010). A developmental perspective on executive function. Child Development, 81, 1641-1660. http://dx.doi .org/10.1111/j.1467-8624.2010.01499.x

Blair, C., \& Razza, R. P. (2007). Relating effortful control, executive function, and false belief understanding to emerging math and literacy abilities in kindergarten. Child Development, 78, 647-663.

Blair, C., Knipe, H., \& Gamson, D. (2008). Is there a role for executive functions in the development of mathematics ability? Mind, Brain, and Education, 2(2), 80-89. https://doi.org/10.1111/j.1751-228X.2008.00036.x

Bronson, M. B. (2000). Self-Regulation in early childhood: Nature and nurture. New York, NY: Guilford Press.

Bronson, M. B., Goodson, B. D., Layzer, J. J., \& Love, J. (1990). Child Behavior Rating Scale. Cambridge, M. A: Abt. Associates.

Bryce, D., \& Whitebread, D. (2012). The development of metacognitive skills: Evidence from observational analysis of young children's behavior during problem-solving. Metacognition and Learning, 7(3), 197-217. https://doi.org/10.1007/s11409-012-9091-2

Bryce, D., Whitebread, D., \& Szűcs, D. (2015). The relationships among executive functions, metacognitive skills and educational achievement in 5 and 7 year-old children. Metacognition and Learning, 10(2), 181-198. https://doi.org/10.1007/s11409-014-9120-4

Bull, R., Espy, K. A., \& Wiebe, S. A. (2008). Short-term memory, working memory, and executive functioning in preschoolers: longitudinal predictors of mathematical achievement at age 7 years. Developmental neuropsychology, 33(3), 205-228. https://doi.org/10.1080/87565640801982312

Chun, M. M. (2011). Visual working memory as visual attention sustained internally over time. Neuropsychologia, 49(6), 1407-1409.

Cowan, N. (1995). Attention and memory: An integrated framework. Oxford Psychology Series, No. 26. New York: Oxford University Press

Dawson, P. \& Guare, R. (2010). Executive skills in children and adolescents: A practical guide to assessment and intervention. New York, NY: The Guilford Press.

Dearing, E., Berry, D., \& Zaslow, M. (2006). Poverty during early childhood. In K. McCartney \& D. Phillips (Eds.), Blackwell handbook of early childhood development (pp. 399-423). Malden, MA: Blackwell.

Duncan, G. J., Dowsett, C. J., Claessens, A., Magnuson, K., Huston, A. C., Klebanov, P., Pagani, L. S., Feinstein, L., Engel, M., Brooks-Gunn, J., Sexton, H., Duckworth, K., \& Japel, C. (2007). School readiness and later achievemnet. Developmental Pcychology, 43 (6), 1428-1446

Eisenberg, N., \& Spinrad, T. L. (2004). Emotion-related regulation: sharpening the definition. Child development, 75(2), 334-339. https://doi.org/10.1111/j.1467-8624.2004.00674.x 
Ertürk Kara, H. G., Güler Yıldız, T., Fındık, E. (2018). Erken Cocukluk Döneminde Öz Düzenleme İqleme, Değerlendirme ve Destekleme Yöntemleri. Ankara: Anı Yayıncılık

Evans, G. W., \& Rosenbaum, J. (2008). Self-regulation and the income-achievement gap. Early Childhood Research Quarterly, 23, 504-514.

Fischer, K.W. (2008). Dynamic cycles of cognitive and brain development: Measuring growth in mind, brain, and education. In A.M. Battro, K.W. Fisher \& P. Lena (Eds). The educated brain (pp.127-150). Cambridge UK: Cambridge University Press

Ford, R. M., McDougall, S. J. P., \& Evans, D. (2009). Parent-delivered compensatory education for children at risk of educational failure: Improving the academic and selfregulatory skills of a Sure Start preschool sample. British Journal of Psychology, 100, 773-797.

Gathercole, S. E., \& Pickering, S. J. (2000). Assessment of working memory in six- and seven-yearold children. Journal of Educational Psychology, 92, 377-390.

Gazzaley, A., \& Nobre, A. C. (2012). Top-down modulation: bridging selective attention and working memory. Trends in Cognitive Sciences, 16, 129-135. https://doi.org/10.1016/j.tics.2011.11.014

Gözüm, A. İ. C., Coşkun, M.,\& İpek, Z.H., (2019). The Endless Well in Early Childhood Period: Executive Functions in Classroom Activities. In Alisinanoğlu, F., Bayraktar, V. \& Gözüm, A. İ. C (Eds.), New Horizons in Early Childhood Education (pp.51-65), Klaipeda: Strategic Researches Academy.

Gürbüz, S. (2019). Sosyal Bilimlerde Aracı, Düzenleyici ve Durumsal Etki Analiə̨leri. Ankara: Seçkin Yayinc1lik.

Hayes, A. F. (2018). Introduction To Mediation, Moderation, And Conditional Process Analysis: A RegressionBased Approach. New York: The Guilford Press.

Hooper, D., Coughlan, J., \& Mullen, M. R. (2008). Structural equation modelling: Guidelines for determining model fit. The Electronic Journal of Business Research Methods, 6, 53-60. https://doi.org/ 10.21427/D7CF7R

Howse, R. B., Lange, G., Farran, D. C., \& Boyles, C. D. (2003). Motivation and self-regulation as predictors of achievement in economically disadvantaged young children. Journal of Experimental Education, 71(2), 151-174.

Hu, L.-t., \& Bentler, P. M. (1998). Fit indices in covariance structure modeling: Sensitivity to underparameterized model misspecification. Psychological Methods, 3(4), 424 453. https://doi.org/10.1037/1082-989X.3.4.424

İvrendi, A, \& Erol, A. (2018, Mart, 29-31). 4-6 Yaş Cocuklarna Yönelik Öz-Düzenleme Becerileri Ölçeğinin geliștirilmesi (Öğretmen Formu). 1. Uluslararası Temel Eğitim Kongresinde sunulan sözlü bildiri, Uludağ Üniversitesi, Bursa.

Johnson, K. A., White, M., Wong, P. S., \& Murrihy, C. (2020). Aspects of attention and inhibitory control are associated with on-task classroom behaviour and behavioural assessments, by both teachers and parents, in children with high and low symptoms of ADHD. Child neuropsychology: a journal on normal and abnormal development in childhood and adolescence, 26(2), 219_ 241. https://doi.org/10.1080/09297049.2019.1639654

Jöreskog, K. G., \& Sörbom, D. (1984). Lisrel VI. analysis of linear structural relationships by maximum likelihood, instrumental variables, and least squares methods. Mooresville: Scientific Software. 
Kane, M. J., Bleckley, M. K., Conway, A. R. A., \& Engle, R. W. (2001). A controlled-attention view of working-memory capacity. Journal of Experimental Psychology: General, 130, 169- 183. https://doi.org/10.1037/0096-3445.130.2.169

Kar, B.R., \& Kenderla, P.K. (2017). Working Memory and Executive Attention: Insights from Developmental Studies and Implications for Learning and Education. J Indian Inst Sci, 97, 497-510. https://doi.org/10.1007/s41745-017-0044-2

Karasar, N. (2009). Bilimsel araștırma yöntemleri. Ankara: Anı.

Kiyonaga, A., \& Egner, T. (2014). Working memory as internal attention: Toward an integrative account of internal and external selection processes. Psychonomic Bulletin \& Review. https://doi.org/10.3758/ s13423-012-0359-y

Kline, R. B. (2016). Principle and practice of structural equation modelling (4th ed.). New York, NY: The Guilford Press

Klingberg, T., Forssberg, H., \& Westerberg, H. (2002). Training of working memory in children with ADHD. Journal of clinical and experimental neuropsychology, 24(6), 781-791. https://doi.org/10.1076/jcen.24.6.781.8395

Landry, S. H., Smith, K. E., Swank, P. R., \& Miller-Loncar, C. L. (2000). Early maternal and child influences on children's later independent cognitive and social functioning. Child Development, 71, 358-375.

Lareau, A. (2003). Unequal childhoods: Class, race and family life. Los Angeles: University of California Press.

Macdonald, J. A., Beauchamp, M. H., Crigan, J. A., \& Anderson, P. J. (2014) Age-related differences in inhibitory control in the early school years. Child Neuropsychology, 20(5), 509-526. https://doi.org/10.1080/09297049.2013.822060.

Maraver, M. J., Bajo, M. T., \& Gomez-Ariza, C. J. (2016). Training on Working Memory and Inhibitory Control in Young Adults. Frontiers in buman neuroscience, 10, 588. https://doi.org/10.3389/fnhum.2016.00588

Marsh, H. W., \& Hau, K. T. (1996). Assessing goodness of fit: Is parsimony always desirable? The Journal of Experimental Education, 64(4), 364-390. https://doi.org/10.1080/00220973.1996.10806604

McCabe, D. P., Roediger, H. L., McDaniel, M. A., Balota, D. A., \& Hambrick, D. Z. (2010). The relationship between working memory capacity and executive functioning: evidence for a common executive attention construct. Neuropsychology, 24(2), 222-243. https://doi.org/10.1037/a0017619

McClelland M.M., Cameron, C.E., Duncan, R., Bowles, R.P., Acock, A.C., Miao, A., Pratt, M.E. (2014). Predictors of early growth in academic achievement: The head-toes-kneesshoulders task. Frontiers in Psychology, 5, 1-14. https://doi.org/10.3389/ fpsyg.2014.00599.

McClelland, M. M., \& Cameron, C. E. (2012). Self-regulation in early childhood: Improving conceptual clarity and developing ecologically valid measures. Child Development Perspectives, 6, 136-142. http://dx.doi.org/10.1111/j.1750-8606.2011.00191.x

McClelland, M. M., Cameron, C. E., Connor, C. M., Farris, C. L., Jewkes, A. M., \& Morrison, F. J. (2007a). Links between behavioral regulation and preschoolers' literacy, vocabulary, and math skills. Developmental Psychology, 43, 947-959. 
McClelland, M. M., Cameron, C. E., Wanless, S. B., \& Murray, A. (2007b). Executive function, behavioral self-regulation, and social-emotional competence: Links to school readiness. In O. N. Saracho \& B. Spodek (Eds.), Contemporary perspectives on social learning in early childhood education (pp. 83-107). Charlotte, NC: Information Age.

Meltzer, L., \& Krishnan, K. (2007). Executive function difficulties and learning disabilities. In L. Meltzer (Ed.), Executive Function in Education: From Theory to Practice (pp. 76-104). New York: Guilford Press.

Menard, S. (1995). Applied logistic regression analysis. Thousand Oaks, CA: Sage.

Moffitt, T. E., Arseneault, L., Belsky, D., Dickson, N., Hancox, R. J., Harrington, H. L., Houts, R., Poulton, R., Roberts, B. W., Ross, S., Sears, M. R., Thomson, W. M., \& Caspi, A. (2011). A gradient of childhood self-control predicts health, wealth, and public safety. Proceedings of the National Academy of Sciences of the United States of America, 108(7), 26932698. https://doi.org/10.1073/pnas.1010076108

Myers, R. (1990). Classical and modern regression with applications ( $\left.2^{\text {nd }} \mathrm{ed}\right)$. Boston, MA: Duxbury.

Nelson, C.A. (2002). Neural development and life-long plasticity. In R.M. Lerner, F. Jacobs, D. Wetlieb (Eds.), Promoting positive child, adolescent and family development: Handbook of program and policy interventions. Thousand Oaks, CA: Sage Publications.

Norris, G., \& Tate, R. L. (2000). The Behavioural Assessment of the Dysexecutive Syndrome (BADS): Ecological, concurrent and construct validity. Neuropsychological Rehabilitation, 10(1), 33-45. https://doi.org/10.1080/096020100389282

Oberauer, K. (2009). Design for a working memory. Psychology of Learning and Motivation: Advances in Research and Theory, 51, 45-100. https://doi.org/10.1016/S00797421(09)51002-X

Oberauer, K. (2019). Working Memory and Attention - A Conceptual Analysis and Review. Journal of Cognition, 2(1), 36. http://doi.org/10.5334/joc.58

Olivers, C. N. L. (2008). Interactions between visual working memory and visual attention. Frontiers in Bioscience, 13, 1182-1191. https://doi.org/10.2741/2754

Parker, B. C. (2001). The relationship between attention and memory and school readiness in west virginia preschoolers. (Dissertation for the degree of master of arts). Marshall University, West Virginia.

Passolunghi, M. C., \& Siegel, L. S. 2001. Short-term memory, working memory, and inhibitory control in children with difficulties in arithmetic problem solving. Journal of Experimental Child Psychology, 80: 44-57.

Paulson, D.S. (2007). Handbook of regression and modeling. Florida: Chapman \& Hall/CRC.

Ponitz, C. C., McClelland, M. M., Matthews, J. S., \& Morrison, F. J. (2009). A structured observation of behavioral self-regulation and its contribution to kindergarten outcomes. Developmental psychology, 45(3), 605-619. https://doi.org/10.1037/a0015365

Ram-Tsur, R., Nissim, M., Zion, M., Ben-Soussan, T.D., \&Mevarech, Z. (2013). Language Development: The effect of aquatic and on-land motor interventions. Creative Education, 4(9), 41-50.

Raver, C., \& Blair, C. (2016), Neuroscientific insights: Attention, working memory and inhibitory control. The Future of Children, 21(2),95-118. 
Rennie, D. A. C., Bull, R., \& Diamond, A. (2004). Executive functioning in preschoolers: Reducing the inhibitory demands of the dimensional change card sort task. Developmental Neuropsychology, 26, 423-443.

Riggs, N. R., Blair, C. B., \& Greenberg, M. T. (2003). Concurrent and 2-year longitudinal relations between executive function and the behavior of 1 st and 2 nd grade children. Child Neuropsychology, 9, 267-276.

Robert, C., Borella, E., Fagot, D., Lecerf, T., \& de Ribaupierre, A. (2009). Working memory and inhibitory control across the life span: Intrusion errors in the Reading Span Test. Memory \& Cognition, 37(3), 336-345. https://doi.org/10.3758/MC.37.3.336

Sezgin, E., \& Demiriz, S. (2016). Çocuk Davranış Değerlendirme Ölçeğì' nin (ÇODDÖ) Türkçe' ye Uyarlanması: Geçerlik ve güvenirlik çalışmas1. Mersin Üniversitesi Eğitim Fakültesi Dergisi, 12(2), 702-718.

Shanahan, M. A., Pennington, B. F., \& Willcutt, E.W. (2008). Do motivational incentives reduce the inhibition deficit in ADHD? Developmental Neuropsychology, 33(2), 137-159.

Shevlin, M., \& Miles, J. N. V. (1998). Effects of sample size, model specification and factor loadings on the GFI in confirmatory factor analysis. Personality and Individual Differences, 25(1), 8590. https://doi.org/10.1016/S0191-8869(98)00055-5

Shipstead, Z., Lindsey, D. R. B., Marshall, R. L., \& Engle, R. W. (2014). The mechanisms of working memory capacity: Primary memory, secondary memory, and attention control. Journal of Memory and Language, 72, 116141. https://doi.org/10.1016/j.jml.2014.01.004

Shipstead, Z., Martin, J. D., \& Nespodzany, A. (2019). Visuospatial working memory, auditory discrimination, and attention. Memory (Hove, England), 27(4), 568-574. https://doi.org/10.1080/09658211.2018.1532010

Sonuga-Barke, E. J., Dalen, L., Daley, D., \& Remington, B. (2002). Are planning, working memory, and inhibition associated with individual differences in preschool ADHD symptoms?. Developmental neuropsychology, 21(3), 255-272.

St. Clair-Thompson, H., Stevens, R., Hunt, A., \& Bolder, E. (2010). Improving children's working memory and classroom performance. Educational Psychology, 30(2), 203-219.

Stevens, J., Quittner, A. L., Zuckerman, J. B., \& Moore, S. (2002). Behavioral inhibition, selfregulation of motivation, and working memory in children with attention deficit hyperactivity disorder. Developmental neuropsychology, 21(2), 117-139. https://doi.org/10.1207/S15326942DN2102_1

Swanson, H. L., \& Beebe-Frankenberger, M. (2004). The relationship between working memory and mathematical problem solving in children at risk and not at risk for serious math dificulties. Journal of Educational Psychology, 96, 471-491.

Swayze, M., \& Dexter, C. (2017). Working memory and school readiness in preschoolers. Contemporary School Psychology, 40688, 1-11.

Sweeney, J. A., Rosano, C., Berman, R. A., \& Luna, B. (2001). Inhibitory control of attention declines more than working memory during normal aging. Neurobiology of aging, 22(1), 3947. https://doi.org/10.1016/s0197-4580(00)00175-5

Tabachnick, B. G., \& Fidell, L. S. (2013). Using multivariate statistics (6 ${ }^{\text {th }}$ ed.). United States: Pearson Education. 
Tiego, J., Testa, R., Bellgrove, M. A., Pantelis, C., \& Whittle, S. (2018). A hierarchical model of inhibitory control. Frontiers in Psychology, 9(1339), 1-25.

Tominey, S., \& McClelland, M. M. (2008, April). "And when they woke up . . they were monkeys!" Using classroom games to promote preschoolers' self-regulation and school readiness. Poster presented at the Conference on Human Development, Indianapolis, Indiana.

Traverso, L., Mantini, C., Usai, M. C., \& Viterbori, P. (2015). The Relationship Between Inhibition and Working Memory In Preschoolers: Evidence For Different Inhibitory Abilities. In EAPCogSci. 20 Nisan 2020 tarihinde http://ceur-ws.org/Vol-1419/paper0003.pdf adresinden erişildi.

Unsworth, N., \& Spillers, G. J. (2010). Working memory capacity: Attention control, secondary memory, or both? A direct test of the dual-component model. Journal of Memory and Language, 62, 392- 406. https://doi.org/10.1016/j.jml.2010.02.001

Vohs, K. D., \& Baumeister, R. F. (2004). Understanding self-regulation An introduction. In R. F. Baumeister \& K. D. Vohs (Eds.), Handbook of self-regulation Research, Theory, and Applications (pp. 1-9). New York, NY The Guilford Press.

Walcott, C. M., Scheemaker, A., \& Bielski, K. (2010). A longitudinal investigation of inattention and preliteracy development. Journal of attention disorders, 14(1), 79-85. https://doi.org/10.1177/1087054709333330

Zimmerman, B. J. (2000). Attaining self-regulation: A social cognitive perspective. In M. Boekaerts, P. R. Pintrich, \& M. Zeidner (Eds.), Handbook of self-regulation (p. 13-39). Academic Press. https://doi.org/10.1016/B978-012109890-2/50031-7 